\title{
ORIGEM DA ENFERMAGEM PEDIATRA MODERNA
}

\author{
Semiramis Melani Melo Rocha* \\ Maria Cecilia Puntel de Almeida*
}

ROCHA, S.M.M.; ALMEIDA, M.C.P. de Origem da enfermagem pediatra modema. Rev Esc. Enf. USP., v. 27, n. 1, p.25-41, abr. 1993.

Este estudo tem por objetivo analisar a origem da enfermagem pediatra moderna intitucionalizada em meados do século XIX tomando-se o conhecimento como instrumento de apreensão do objeto de trabalho pelo homem. De uma perspectiva histórica, a enfermagem é entendida como prática socialmente articulada, parte de um processo coletivo de trabalho, cujas finalidades são o controle da doença na sociedade a nível coletivo e a recuperaçāo individual da força de trabalho.

Mediante bibliografia selecionada, procura-se identificar as características da assistência de enfermagem à criança na Inglaterra, no século XIX e os movimentos sumultâneos da prática médica: Medicina Social, Prática Médica Clínica e Puericultura. A seguir, são analisadas as caracteristicas da assistência à criança nos Estados Unidos na primeira metade deste século e o seu referencial teórico.

UNITERMOS: Histórico da Enfermagem Pediatra.

\section{INTRODUÇĀO}

$\mathrm{Na}$ área médica há poucos estudos destinados a entendê-la como prática social, articulada a uma sociedade concreta, além de seus aspectos técnicos e científicos. Destacam-se os trabalhos de FOUCAULT ${ }^{4,5}$ e ROSEN ${ }^{11,12}$. Temse observado que na Enfermagem há no momento, uma preocupação em investigar sua origem como trabalho necessário socialmente, transformandose, portanto, em diferentes épocas e locais.

O objeto đesta investigação é a origem da enfermagem pediatra moderna, tomando-se o conhecimento como instrumento privilegiado no processo de trabalho que permite identificar o objeto, a finalidade, os agentes e transformaçōes operadas. Através de bibliografia selecionada procura-se identificar as características da assistência à criança na Inglaterra no século XIX e nos Estados Unidos, na primeira metade deste século.

As determinações genéricas e mais abstratas do processo de trabalho na formação econômica e social capitalista estão expressas na obra de MARX ${ }^{6}$, sobretudo em O Capital. Este referencial teórico foi reelaborado por MENDES GONÇALVES $^{7,8}$ para apreender o processo de trabalho em saúde e sua

* Professores associados do Departamento de Enfermagem Materno-Infantil e Saúde Páblica da Escola de Enfermagem de Ribeirăo Pre to da Universidade de Săo Paulo.

Este trabalho foi parcialmente financiado pelo Conselho Nacional de Desenvolvimanto Científico e Tecnokgico (CNPq). 
organização tecnológica em nossa sociedade. Fundamentando-se nestas concepções teórico-metodológicas e em outros autores que vêm estudando a enfermagem como prática social, desenvolveu-se esta investigação.

To ma-se como ponto de partida duas características essenciais do trabalho humano: a sociedade e a historicidade. A socialidade refere-se ao fato de que as necessidades e carências que presidem o processo são sempre e necessariamente coletivas. Além disso, o processo de trabalho estabelece relações entre os homens através de seus produtos e na própria atividade de produção. A historicidade diz respeito às variaçōes geradas pelas necessidades e de sua satisfação através do trabalho, dentro do quadro particular de cada estrutura social.

A divisão social do trabalho é uma característica de todas as sociedades em todas as épocas. Identificamos esta divisão em setores classificados em produtores de bens e serviços, dentre eles a saúde, a educação, o comércio, as comunicações. A prática médica e as práticas de saúde constituem-se no mesmo movimento social conjunto em que o modo de produção é gerado. Iniciada a transiçāo para o capitalismo, nem as necessidades em saúde, nem a capacidade de satisfazê-las, estavam dadas. Os agentes sociais desse trabalho foram efetivamente capazes de responder a essas demandas em sua contínua transformação na prática.

Por historicidade das práticas médicas e da enfermagem entende-se nāo a origem, difusāo e consecução de um processo de trabalho onde se vão constituindo progressivamente, numa evoluçāo cumulativa de conhecimentos, um projeto idealizado de assistência à saúde. Entende-se historicidade como transformações que ocorrem no objeto e finalidade do processo, bem como na formação, denominação e atividades desempenhadas por seus agentes, e sobretudo no corpo de conhecimentos que preside o processo, de acordo com as contingências das relacōos sociais.

Assim, a tese que se pretende desenvolver é a seguinte: em cada época e em cada sociedade concreta variam as necessidades em saúde, logo variam no processo de trabalho o objeto, a finalidade, os agentes e suas funçōes e principalmente o conhecimento, instrumento fundamental do processo. Essas variações decorrem das articulações do setor saúde com os outros setores sociais.

Indaga-se, pois:

Qual a necessidade posta para a assistência à criança na institucionalização da enfermagem moderna, a qual trabalho responde? Qual o carecimento social em relação à saúde da criança que a enfermagem procura suprir? Procura-se a resposta nos saberes acionados para apreender e transformar o objeto no processo de trabalho. 


\section{FLORENCE NIGHTINGALE E OS MOVIMENTOS DA PRÁtiCA MÉDICA}

O livro "Notas sobre Enfermagem: o que é e o que não é" foi escrito por FLORENCE NIGHTINGALE ${ }^{9}$ em 1859. Nesta obra, Nightingale registra o resultado de sua experência de mais de catorze anos no trato com doentes, enfermeiros e hospitais, lançando os fundamentos da enfermagem moderna. Destinada ao grande público, mas de modo especial às mulheres, mães de família, às professoras e às enfermeiras, empregadas em residências ou em hospitais, mostra a possibilidade e a necessidade de uma preparaçāo formal e sistemática para a aquisição de um conhecimento de natureza distinta daquele buscado pelos médicos.

Em se tratando de uma obra considerada como marco da enfermagem moderna, optou-se por utilizá-la para estudar a primeira abordagem que se fêz à assistência de enfermagem à criança.

Inicialmente, NIGHTINGALE ${ }^{9}$ amplia o conceito de enfermagem, até então limitado à ministração de medicamentos e aplicações de cataplasmas, propondo a percepção da doença como um esforço da natureza para restaurar a saúde. Caberia à enfermagem favorecer este processo reparativo, mediante o uso de ar puro, do calor, da limpeza, do repouso e da dieta, com o mínimo de dispêndio de energias do paciente, mantendo-o nas melhores condições para que a natureza pudesse agir.

Refere-se especificamente à criança em várias passagens do livro, e, em capítulo específico "Atendimento à criança", acrescentado na terceira edição de 1861. Em uma destas passagens sob o título "Estranhas deduções sobre uma taxa exagerada de mortalidade" NIGHTINGALE critica a solicitação, publicada em um jornal londrino, de um hospital infantil, para solucionar o problema de altos índices de mortalidade de crianças menores de 10 anos. Segundo ela, as causas de mortalidade são as condições de higiene doméstica deficientes e entre os remédios não estaria incluida a construção de um hospital. Sua crítica estende-se à educação das mulheres de todas as classes sociais, professores e enfermeiras, que não aprendem as leis que ajudam a promoçăo e preservação da saúde de seus filhos. Adverte que, com as medidas e normas para a preservação das boas condições sanitárias das habitações, as crianças nāo precisam necessariamente ter o que se denomina em geral "epidemias infantis", sarampo, coqueluche e até mesmo escarlatina, o que parecia ser uma opinião popular na época.

No capítulo específico sobre "assistência à criança" em tom mais coloquial, dirige-se às senhoritas que cuidam de crianças, reforçando a necessidade de cuidados redobrados em observação e atenção.

No apêndice, NIGHTINGALE ${ }^{9}$ apresenta o número de mulheres empregadas como enfermeiras na Grã-Bretanha, de acordo com o senso de 1851. Estas enfermeiras são distribuidas em três categorias: 25.466 enfermeiras em 
serviço não doméstico, 39.139 trabalhando em serviços nos domicílios e 2.822 parteiras. Dentre as 39.139 enfermeiras trabalhando em serviços domésticos, 508 tinham 5 anos de idade, 7.25910 anos e 10.355, 15 anos. Portanto, 46,30\% eram menores de 15 anos. Provavelmente dentre estas cstavam as enfermeiras que cuidavam de crianças nos lares ingleses.

Entre os vários cuidados recomendados por NIGHTINGALE ressalta-se:

- Criança desmamada deve ser alimentada regularmente muitas vezes e não demasiadamente de cada vez.

- Entreter uma criança de forma a deixá-la brincar livremente c, ao mesmo tempo, cuidar para que não corra perigo.

- Considerando que as enfermeiras que cuidam de crianças são muito jovens, adverte para a necessidade de terem muita responsabilidade.

- Necessidade da criança de respirar ar puro.

- Não expor uma criança a uma corrente de ar, especialmente quando docnte.

- Conservar a criança limpa. Banhá-la uma ou duas vezes por dia, além de lavá-la toda vez que urinar.

Por estas recomendaçōes entende-se que NIGHTINGALE estruturou uma concepção sobre cuidados preventivos a serem dispensados à criança, referentes à alimentação, à recreação, à higiene pessoal e ao ambiente, bem como preocupação com certas características pessoais que conferem competência a quem exerce a enfermagem, como responsabilidade e bom-senso.

Compreende-se que os cuidados recomendados devam ser dispensados, genericamente às crianças sadias em seu domicílio. Pelo texto, parece ser usual entregar as crianças aos cuidados destas jovens, embora não disponham de preparo específico em enfermagem.

NIGHTINGALE lança, assim, os fundamentos da enfermagem pediatra, centrada bem mais em puericultura, que já vinha sendo definida na França, onde teve sua origem, como o conjunto de regras e noções sobre a arte de criar fisiológica e higienicamente as crianças. A origem da puericultura $\mathrm{em}$ fins do século XVIII, seu desenvolvimento e suas relaçōes com a enfermagem foram discutidas em trabalho anterior. ${ }^{10}$

Quando NIGHTINGALE editou "Notas sobre enfermagem" juntamente com "Notas sobre hospitais", em 1859, ainda não estava criada a escola de cnfermagem sob sua orientação, o que veio a ocorrer $\mathrm{cm} 09$ de julho de $1860^{14}$. Entretanto, os fundamentos da medicina preventiva e medicina social produziam-se há dois séculos. Na Inglaterra, França e Alemanha vinha se desenvolvendo, desde o século XVII, a idéia de uma política nacional de saúde, compatível com o desenvolvimento do comércio e da indústria e a consequente urbanização. O controle das doenças transmissíveis, a prevenção da mortalidade infantil e a redução da populaçāo eram associados à produtividade no trabalho e à prosperidade do país. Entretanto, há diferenças no processo 
histórico destes três Estados, onde ocorrem as transformações em busca de soluções para problemas médicos e de saúde familiares, comunitários e institucionais. Rosen ${ }^{11}$ descreve este movimento $e$ as novas necessidades emergentes específicas em cada um.

Em fins do século XVIII alcançou-se, nos Estados Alemães, um sistema de pensamento e comportamento administrativo que atribuia, como norma, ao Estado absoluto, todas as atividades para o bem-estar.

O conceito de política médica, termo empregado a partir de 1764 , concentra as relações entre a medicina, a saúde e o Estado: regulamentação da educação médica, supervisão de farmácias e hospitais, combate ao charlatanismo e esclarecimento público. Ao médico compete não apenas tratar o doente, mas também supervisionar a saúde da população. Através da higiene pública, o Estado atua na saúde infantil, do escolar, gravidez e nas condiçōes do meio ambiente: iluminação, aquecimento, ventilação, alimentação, vestuário, recreação, habitação e prevenção de acidentes.

As idéias contidas no conceito de política médica propagam-se para França, Grã-Bretanha, Estados Unidos, além de outros países mais próximos dos Estados Alemães, estando já amplamente divulgadas no século XIX. Tratava-se, porém, de idéias autoritárias e paternalistas. O processo de desenvolvimento econômico na França no século XVIII e XIX criou tensões e pressōes refletindo na evolução do pensamento e da ação francesa sobre a saúde. No século XIX, sendo a França o país mais avançado em teoria política e social, produziu numerosos estudos relacionando problemas sociais e saúde, fundamentados no empirismo racional, na observação crítica, levantamentos e análises estatísticas. Tomando as próprias cidades como objeto de ação médica, a medicina urbana, na França, desenvolve a noção de salubridade correlata à noção de meio ambiente.

O conceito de política médica, do modo como se desenvolveu na Alemanha, dificilmente poderia florescer na Gră-Bretanha, no século XIX, onde o liberalismo econômico era a doutrina prevalente. Neste ambiente, não se desenvolveram análises sociais da saúde e da doença e nenhuma formulação teórica comparável à dos franceses e alemães foi elaborada. Apesar disso, formula-se uma consciência pública sobre as más condiçōes de vida da população, alteradas pela Revolução Industrial, exposta às doenças em habitaçōes precárias, ocupações perigosas e prejudiciais e às excessivas taxas de mortalidade e morbidade. O reconhecimento empírico das relações entre os problemas sociais e a atuação médica deu origem à organização de uma política social para o cuidado da saúde. $O$ interesse crescente em saúde pública levou as autoridades a tomarem inúmeras medidas; dentre elas, o St. Thomas Hospital, em 1856, estabelece um curso expositivo em saúde pública, o primeiro desta espécie na Inglaterra cujo conteúdo versava sobre prevençāo de doenças e suas 
relaçōes com o sistema social. A relaçāo entre mortalidade infantil e o emprego das mães na fábrica tornou-se um dos objetos de estudo.

"Política médica, higiene social, medicina do espaço urbano, todas denominaçōes que encobrem em detalhes c particularidades o mesmo amplo movimento comum de adaptação do saber c da prática à realidade nova" ${ }^{\prime 7}$.

Com estes instrumentos teóricos, diante de uma nova necessidade social, NIGHTINGALE delineia seu objeto de trabalho - a assistência de enfermagem - apreendendo-o através de um recorte intelectual, que lhe permitiu reformular uma dentre as várias práticas em saúde que se reestruturam no século XIX. A assistência à criança é vista em sua dimensāo coletiva. São normas e regras gerais sobre higiene e alimentação da criança. Este recorte intelectual nāo está centrado no indivíduo, ou nos corpos individuais, mas no ambiente, visando ao coletivo. Não utiliza a fisiopatologia como teoria na apreensão do objeto de análise e trabalho e sim o saneamento, condições de higiene, do ar, água, moradia, roupas e pessoal. Desprendida do corpo humano individual, a enfermagem proposta por NIGHTINGALE desenvolve a noçāo de salubridade correlata à noção de higiene do meio ambiente como fundamentos para exercer a enfermagem. Como instrumentos de trabalho propõe a observação, normatização de procedimentos, disciplina e hierarquização de funçōes.

A obra de NIGHTINGALE, em seu conjunto está voltada para a organização da assistência de enfermagem hospitalar, prioritariamente. Contudo, na Inglaterra, por volta de 1850 , o hospital ainda estava se organizando como núcleo da prática médica clínica, individualizada. Os doentes hospitalizados ainda eram os soldados, os velhos e os pobres. Os doentes que possuiam família eram tratados no domicílio c não se instituira ainda a pediatria como especialização médica.

Os primeiros conceitos e trabalhos sobre puericultura estavam se organizando sobretudo na França, de onde se propagam para os outros países. A aprecnsão da criança pela medicina se dá, inicialmente, através de conhecimentos que possibilitem crescimento e desenvolvimento saudável, através da higiene corporal e do ambiente, alimentação, cuidados pré-natais e pósnatais imediatos. Medidas lega is para protegêt-la dos agravos do meio ambiente começam a ser adotadas, como a regulamentação do trabalho da puérpera, possibilitando que a mãe cuide da criança nos primeiros meses, proteção da criança contra trabalhos insalubres, entre outras. A enfermagem, com NIGHTINGALE, também delineia sua apreensão da assistência à criança com o mesmo recorte intelectual. Logo, observa-se uma articulação histórico social da concepção teórica formulada por NIGHTINGALE com a racionalidade científica e a prática médica hegemônica deste período histórico.

O hospital, instrumento terapêutico, parte da tecnologia médica data do final do século XVIII. Tratava-șe até então de uma instituição de assistência aos pobres, tendo também por finalidade separar o doente do convívio social 
protegendo os outros do perigo que ele representava. A experiência hospitalar ainda nāo estava incluída na prática médica e na formação do médico, que, nesta época, se fazia através de textos e transmissão de receitas. O ponto de partida da reforma hospitalar ocorreu face a necessidade de purificar o hospital de seus efeitos nocivos e da desordem que ele acarretava, nāo só disseminando doenças, mas também como foco de desordem econômico social ${ }^{4,5}$.

Primeiramente, são produzidos mecanismos disciplinares no espaço confuso do hospital possibilitando sua medicalização. Soma-se a este fato a transformaçāo que ocorre no saber médico. Surge, no século XVIII, como modelo para inteligibilidade da doença, a botânica classificatória de Lineu. Por este modelo, compreende-se a doença como fenômeno natural, com característica e desenvolvimento possíveis de classificação em espécies: "A doença é a natureza, mas uma natureza devida a uma ação particular do meio sobre o indivíduo"

Nessa perspectiva, a cura é dirigida por intervenção médica que se endereça não mais à doença propriamente dita, mas ao que a circunda: o ar, a água, a temperatura ambiente, o regime, a alimentação. A disciplina hospitalar terá por função assegurar o esquadrinhamento e a vigilância do mundo do doente, possibilitando o registro de todos os acontecimentos a ele relacionados. Ao mesmo tempo, o hospital terá a função de transformar as condiçōes do meio em que os doentes são colocados, o ar que respiram, a água que bebem, a temperatura ambiente, como instrumento com função terapêutica, através de seu próprio espaço. Neste momento, o médico passa a ser o principal responsável pela organização hospitalar -transforma-se o sistema de poder no interior do hospital, invertendo-se as relações hierárquicas entre o médico e o clero.

Organiza-se, pois, um sistema de registro permanente de ocorrências no interior do hospital, ou seja um campo documental que não é somente um lugar de cura, mas também de registro, acúmulo e formação de saber. Ao mesmo tempo em que o hospital permite a observação e o registro de grande número de indivíduos, o indivíduo emerge como objeto do saber e da prática médica.

A aplicação đo conhecimento bacteriológico e estudos de laboratório na Medicina Clínica levaram a um crescimento do número de pessoal médico e técnica exigido pelo hospital no século XX. As mudanças ocorriam nos hospitais e nas comunidades que eles serviam. Impôs-se a necessidade de separar os pacientes por categorias ou grupos apropriados. São contruídos pavilhões especiais àqueles com doenças contagiosas, salas de cirurgia, considerando os princípios de assepsia e laboratórios hospitalares, sendo os primeiros instalados por volta de 1890 . Durante este período sucede a reforma da enfermagem, são introduzidas escolas de treinamento para enfermeiras. Simultaneamente, cresce o reconhecimento do valor do médico à cabeceira do 
doente. Todos esses fatores provocam mudanças na administração hospitalar ${ }^{12}$.

\section{A ENFERMAGEM PEDIATRA NOS ESTADOS UNIDOS}

WAECHTER; BLAKE ${ }^{16}$, no capítulo introdutório do livro texto "Enfermagem Pediátrica" citam, como marco inicial da assistência à criança, a construção do primeiro hospital infantil em Paris, em 1802, seguido pelo "Hospital for Sick Children", em Londres, precursores dos hospitais norteamericanos.

Nos Estados Unidos, os primciros hospitais infantis foram construídos $\mathrm{cm}$ Philadelphia, em $1855 \mathrm{c} \mathrm{cm}$ Boston, em 1896. A criação destes hospitais e de enfermarias de pediatria em hospitais gerais geraram uma nova necessidade: o treinamento cspecífico e a experiência clínica em pediatria, requisitos à habilitaçāo profissional de enfermeiros ${ }^{12}$.

A origem da enfermagem pediatra moderna aparece também associada à pediatria como especialidade médica, por volta de 1888 , com a criação de Departamentos de Pediatria nas cscolas médicas e a função da American Pediatric Society.

"O reconhecimento da necessidade de instrução especial para enfermeiras na assistência à criança ć mais ou menos paralelo ao desenvolvimento de unidades separadas para a assistência à criança que apareceram primeiro em orfanatos, depois em hospitais infantis e, finalmente, nas unidades pediátricas nos hospitais gerais. Mas somente apos os departamentos de pediatria terem se estabelecido firmemente nas escolas médicas foi que a pediatria tornou-se conpulsória nos currículos das escolas de enfermagem ${ }^{.15}$

Citam-se, ainda, como importantes por sua influência na assistência à criança, agências nacionais públicas ou privadas: o estabelecimento do "Children's Bureau", em Washington, em 1912, para investigação de assuntos referentes ao Bem-estar da Criança; o Smith - Lever Act de 1914, provendo fundos para o avanço da educação no Bem-estar da Criança; o Shepherd Towner Act de 1921 provendo os Centros de Higiene e Bem-estar da Maternidade e da Infância e a criação da American Child Health Association em 1923, uma combinação de várias organizações interessadas no estudo e implementação de Saúde da Criança.

Na descrição de WAECHTER; BLAKE ${ }^{16}$ a assistência de enfermagem à criança hospitalizada, até a década de 30 "era feita segundo condutas rígidas com respeito aos procedimentos de enfermagem, isolamento, repouso no leito c regulamento de visita. Essas condutas eram determinadas em parte pela natureza da doença c por firmes conviç̧ōes sobre o que era necessário para a criança doente".

As infecções, sem o auxílio dos antibióticos, eram graves e temidas e o perigo da infecção cruzada dentro do hospital estava sempre presente. As 
regras e técnicas de isolamento eram rígidas. As visitas, ameaça à manutenção correta do isolamento, eram desestimuladas. Uma firme crença na virtude do "repouso absoluto no leito" prolongado mantinha as crianças isoladas uma das outras e confinadas, freqüentemente, com camisa de força à área de sua própria cama.

A finalidade das escolas de enfermagem criadas pelos hospitais norteamericanos no início deste século, era dupla: prover assistência aos pacientes indigentes por meio do trabalho das estudantes e preparar enfermeiras para a comunidade. A primeira finalidade predominou, isto $\epsilon$, prover o hospital de serviço de enfermagem, provocando um deterioramento do ensino e retrocesso na organização das escolas ${ }^{3}$. A "National League of Nursing Education" nasce com o propósito de exercer controle sobre o ensino de enfermagem nos Estados Unidos e Canadá. Em 1917 publica o "Standard Curriculum for Nursing Schools", a primeira tentativa concreta para a padronização dos currículos das escolas. Entre outras sugestōes, este currículo propõe: curso de três anos de duração; exigência de secundário completo como requisito de ađmissão; prática obrigatória nos diversos serviços hospitalares assim distribuída: dez meses em serviço de medicina geral; oito em cirurgia geral; três em obstetrícia; quatro em pediatria.

Em 1927 o "Standard Curriculum" foi revisto introduzindo-se um aumento no total de aulas teóricas, modificando a relação entre teoria e prática que era de 1:10 para 1:63.

Em um programa de enfermagem pediátrica - "SAINT FRANCIS HOSPITAL SCHOOL OF NURSING" ${ }^{13}$ - os autores fazem sérias críticas à formação de enfermeiras, com respeito à qualificação para assistência à criança. Embora não datado, na Introdução, página 2, refere-se à época em que está sendo proposto, logo após a Segunda Guerra Mundial: "Há uma grande necessidade de enfermeira pediatras, bem como de hospitais e médicos. Diante do problema de escassez de pessoal nesta era pós-guerra, a Academia de Pediatria recomenda a melhor preparação educacional de médicos e enfermeiras para o cuidado à criança, durante seus estudos e estágios hospitalares. ${ }^{13}$

A finalidade desta programação é preparar estudantes de enfermagem para o campo de pediatria do hospital onde foi planejado, podendo, entretanto, estender-se a outros hospitais. Estabelecendo o problema, expressa-o da seguinte forma:

"A compreensão do paciente e sua reação mental e emocional à doença não tem progredido tão rapidamente como a tecnologia médica. Este curso está planejado com ênfase na criança como um indivíduo, e o efeito que a doença tem sobre ela como pessoa, ao invés de meramente estudar a própria doença. O ensino em classe e a experiência em enfermarias serão integrados através do programa clínico"13. 
Os autores reconhecem que os instrutores de pediatria omitiam a importância do crescimento e desenvolvimento, das reaçōes psicológicas da criança e da necessidade de educar. Como resultado, as enfermeiras pediatras estavam preparadas para cuidar de crianças no processo agudo da doença, entretanto mostraram-se despreparadas em conduzir a criança durante sua convalescença. Em razão destas áreas negligenciadas, a "League of Nursing Education", em seu estudo "Nursing of Children" (1937), inclui psicologia infantil, enfermagem escolar, observação do pré-cscolar e educaçãa de pais, para desenvolver um curso bem fundamentado em pediatria. ${ }^{13}$ Diante das críticas levantadas e da urgência em preparar enfermeiras pediatras, propõe uma disciplina equilibrada com teoria e prática integradas no programa, preparando a enfermeira para cuidar da criança como um todo.

O Quadro I, em anexo, apresenta a síntese da programação, com a distribuição de assuntos por carga horária desta disciplina de pediatria para enfermeiras cuja orientação vem da "National League of Nursing Education" proposta em 1947. Esta disciplina, oferecida no segundo ano do curso de enfermagem, seria precedida pelas disciplinas enfermagem obstétrica, cirúrgica e médica, sempre que possível.

Fundamentado neste histórico pode-se delinear o referencial teórico que se consolidou a partir dos descobrimentos de Pasteur, citado como a "era bacteriológica" da prática médica. Por este referencial, a possibilidade de identificação de agentes causais microbianos traz um novo instrumental tecnológico à enfermagem. O hospital, já disciplinado e hierarquizado, com seu ambiente sob controle, passa a ser também o local para tratar através do isolamento, sob o olhar vigilante da enfermeira.

A era bacteriológica teve início em torno de 1880 , com os trabalhos básicos de Louis Pasteur (1822-1895) e Robert Koch (1843-1910), os fundadores da bacteriologia. A noção de que as bactérias são causas de doenças é mencionada em trabalhos mais antigos, buscando esclarecer a natureza do contágio e do miasma.

Em 1840 HENLE expôs com clareza as suas idéias sobre o contágio e o miasma, mostrando que não havia diferença entre eles, estabelecendo as condições para que um agente particular possa ser considerado causador de uma doença infecciosa:

- deve ser encontrado com constância no corpo do doente;

- deve ser possível isolá-lo e, com tal agente isolado, reproduzir experimentalmente a doença.

Nas palavras de BIER,

"a implantaçāo definitiva da origem microbiana das doenças infecciosas só teve lugar em 1878, após a sensacional comunicação de Pasteur e col. sobre a teoria dos germes, fruto de investigaçōes exaustivas sobre as fermentaçōes 
e a geração espontânea"..,O período 1880-1900 é, positivamente, o tempo áureo da Bacteriologia.

Até a década de 30 temos poucos registros sobre o conhecimento em enfermagem pediátrica, além da descrição de técnicas. Os relatos históricos, feitos posteriormente, descrevem a assistência a criança instrumentalizada sob o recorte intelectual do referencial da bacteriologia, isto é, na relação causaefeito entre microrganismo e infecção. As doenças transmissíveis são as doenças identificadas e as crianças são hospitalizadas para serem mantidas isoladas.

Os antimicrobianos, até esta época, não haviam sido descobertos ou comercializados e o isolamento, em si mesmo, era o tratamento.

O modelo epidemiológico, conhecimento da saúde e da doença, tomados em sua dimensão coletiva, também se caracterizou, a partir dos descobrimentos de Pasteur, pelo que se convencionou chamar de "era bacteriológica". MENDES GONÇALVES, analisando este movimento faz as seguintes consideraçōes:

"Através do reconhecimento do modo de transmissão das doenças infecciosas era possível deslocar todas as ações destinadas a contê-las à intervenção sobre os elos "mais frágeis" da cadeia epidemiológica situados no meio ambiente, cortando os nexos entre as formas de organização social e a doença e sepultando provisoriamente os programas de reforma social propugnados pela Medicina Social. ${ }^{7}$

As enfermeiras pediatras identificam as limitaçōes deste referencial teórico, ao final da década de 30 , não pela impossibilidade de explicar os determinantes sociais da doença, sim por sua insuficiência $\mathrm{cm}$ fornecer elementos para lidar com a criança, um ser em crescimento e desenvolvimento, temporariamente afastado de seu ambiente e da família, durante a hospitalização.

O programa de Enfermagem Pediatra, disciplina oferecida no SAINT FRANCIS HOSPITAL SCHOOL OF NURSING, Hartford Connecticut, aqui exposto, sintetiza o conhecimento em enfermagem pediatra do período entre 1930 e 1940. Percebe-se na apresentação, um questionamento sobre a forma, até entāo utilizada, de cuidar da criança, compreendida como "um caso" ou a própria "doença". Propõe apreender a criança como um indivíduo, percebendo o efeito que a doença tem sobre ela como pessoa, sua reação mental e emocional, com a particularidade de estar em fase de crescimento e desenvolvimento. Apesar desta proposta, em 70,3\% do currículo (unidades IV e V) a doença é tomada como objeto de ensino.

Às doenças transmissíveis reserva-se a maior carga horária, 43,3\% do total. A temática é bastante explorada, incluindo um amplo elenco de doenças transmissíveis específicas da infância. Os cuidados de enfermagem incluem 
técnicas de isolamento, técnicas relacionadas à terapêutica como o uso do pulmão de aço, em casos de poliomclite com paralisia da musculatura torácica, uso do aspirador e cuidados com a traqueostomia para possibilitar a respiração em caso de obstrução de vias aéreas superiores, como na difteria. Incluem ainda medidas relacionadas à saúde coletiva, como a educação em saúde e a notificação de casos de infecção ao departamento competente.

A segunda unidade, $\mathrm{cm}$ ordem decrescente por distribuiçāo de carga horária é a "Enfermagem nas Doenças do Lactante e da Criança", com 27,0\% do total, onde a temática refere-se às doenças por aparelhos e sistemas, segundo a clínica anátomo-patológica: doenças dos aparelhos ou tratos respiratório, circulatório, urinário, gastro-intestinal e dos sistemas nervoso e músculo-esquelético. A a natomia patológica chega à enfermagem constituíndo-se em um dos elementos construtivos da enfermagem pediátrica. A cada grupo de docnças associam-se técnicas de enfermagem inseridas nos exames subsidiários ou na tcrapêutica mais utilizada. Desta forma, somadas às noções sobre patologias do aparelho respiratório, ensinam-sc técnicas de vaporização e cuidados com a criança em tenda de vapor e oxigênio. Técnicas de coleta de urina para cultura, exames de rotina e provas de função renal associadas a patologias do trato urinário. A ênfase da disciplina recai, pois, sobre as patologias e não sobre aspectos do crescimento e desenvolvimento normal da criança. Especificamente, a ênfase da disciplina é desenvolver nos alunos habilidades para executarem procedimentos técnicos.

Segundo FOUCAULT, na prática médica "o que se modifica, fazendo surgir a medicina anátomo-clínica, não é a simples superfície de conta to entre o sujeito cognescente e o objeto conhecido; é a disposição geral do saber, que determina as posiçōes recíprocas e o jogo mútuo daquele que deve conhecer e daquilo que é cognoscível. ${ }^{5}$

Com este novo olhar, o médico faz "aflorar à superfície o que se dispõe em camadas na profundidade; a semiologia não mais será uma leitura, mas o conjunto de técnicas que permite constituir uma anatomia patológica projetiva"s.

..."O olhar anátomo-clínico deverá demarcar um volume; dirá respeito à complexidade de dados espaciais que pela primeira vez em medicina são tridimensionais" ${ }^{15}$.

A enfermeira, sem o acesso a este conjunto de técnicas que revela o invisível, realiza um trabalho subordinado ao saber médico. Desenvolve uma série de técnicas para subsidiar o diagnóstico e o tratamento médico como: irrigação do ouvido, nariz e garganta, administração de fluídos parenteral, procedimentos de coleta de excreçōes para exames laboratoriais, técnicas especiais de alimentação, preparo da criança para punçōes e aplicações de restrições, dentre outras. Aparece aqui a divisāo entre a concepção e a execução do trabalho, entre o conhecer e o fazer divididos entre trabalhadores 
diferentes. Neste momento, o trabalho de enfermagem é um meio dentro do processo de trabalho emrsaúde.

Quanto mais complexa a tecnologia, possibilitando ao médico detalhar o diagnóstico anátomo-patológico, maior a distância entre o médico e a enfermeira na apreensão do objeto - o corpo humano biológico - neste processo de trabalho. Ao médico abrem-se as possibilidades de conhecer em detalhes o funcionamento de 6 rgãos, tecidos e cćlulas e de instrumentalizar seu trabalho voltado, não para a criança aparente, que sofre e precisa de ajuda, mas para o ponto exato anátomo-clínico onde se localiza a lesão. Este conhecimento é trazido para a enfermagem em linhas gerais c superficiais, na medida suficiente para fundamentar suas atividades técnicas, mantendo, contudo, extremamente limitada sua anatomia nestc processo de trabalho. Exatamente por não cnxergar a criança como um corpo anátomo-clínico, a enfermeira é capaz de ver a criança como um ser que, quando docnte, sofre, sente dores, requer tratamentos, sente a ausência da mãe, dos familiares, dos brinquedos. Ao lado das medidas terapêuticas, a criança reclama por atenção, carinho, sobretudo pelo direito de crescer e desenvolver-se integrada em seu meio.

Evidencia-se bem mais na literatura em enfermagem pediatra que na medicina pediatra, o levantamento de problemas apresentados pela criança hospitalizada, assim como referências à necessidades de assistência psicopedagógica à criança doente. A partir da década de 40 , a enfermagem vai buscar referencial teórico que a instrumentalize na satisfação desta carência infantil. Até o momento, a morbidade e mortalidade por doenças transmissíveis, diarréia e doenças respiratórias eram muito altas sendo a preocupação maior salvar-lhes a vida, ainda que deixando traumas pela hospitalização e outras medidas terapêuticas.

Às necessidades nutricionais da criança são reservadas 8 horas, $10,8 \%$ da carga horária. Observa-se entretanto, no desdobramento do programa que o enfoque tende para aspectos individuais e clínicos da alimentação, como um tópico voltado para doenças nutricionais e metabólicas, incluindo sondas nasogástricas e fórmulas terapêuticas.

Emerge o estudo do crescimento e desenvolvimento, reservando-se 13,5\% da carga horária para esta unidade. A criança é categorizada em faixas etárias, enfatizando-se a especificidade de cada uma delas. Destaca-se o prematuro e seus cuidados de enfermagem específicos, como o uso da incubadora e os controles de temperatura e umidade do berçário. O conhecimento do desenvolvimento e crescimento infantil instrumentaliza a enfermeira para lidar com problemas de comportamento e ajudar nas relaçōes entre a criança, a família e o conjunto de pessoas que compõem a equipe de saúde, particularmente na enfermaria. Este recorte intelectual, trazido em aparte da psicologia irá se desenvolver posteriormente, enquanto conhecimento de enfermagem pediatra. 
Na unidade introđutória, (5,4\% da carga horária do programa) aparece, quase como um resquício, uma abordagem ao meio ambiente hospitalar, redução bastante significativa face ao conjunto dos novos conhecimentos introduzidos.

Sucede haver aqui, uma troca conforme a necessidade social que emerge a substituição de um conhecimento por outro, e não o acréscimo evolutivo de novos conhecimentos.

Distribuídas por todo o conteúdo do programa estão presentes as técnicas de enfermagem, específicas do cuidado com a criança. Como demonstraram ALMEIDA; ROCHA ${ }^{1}$, as técnicas foram a primeira expressão do saber na enfermagem, presentes até a atualidade.

\section{CONSIDERAÇÕES FINAIS}

Observa-se, no período compreendido entre as últimas décadas do século $\mathrm{XIX}$ até o final da década de 40 do século $\mathrm{XX}$, uma modificação no conhecimento com que a enfermagem apreendeu o objeto no processo de trabalho de assistência à criança. Inicialmente a necessidade era o controle das doenças transmissíveis em escala social. Para atender a esta necessidade desenvolveuse um projeto de trabalho com a concepção de doença como um fenômeno coletivo. Os instrumentos utilizados referiam-se à higiene do corpo, do meio ambiente e da alimentação.

Florence Nightingale teve um papel importante na organização da enfermagem hospitalar e sua atuação objetiva-se na criação da primeira escola de enfermagem. Contudo, suas recomendaçōes sobre a assistência à criança demonstram que ela estava atenta aos movimentos de sua época. As crianças eram cuidadas no domicílio e sua preocupação era preservar sua saúde através de cuidados preventivos relacionados à alimentação, recreação, higienc pessoal e do ambiente, bem como uma preocupação em orientar mães e pagens sobre a responsabilidade e o bom-senso que deve presidir as ações ao cuidar de bebês.

$\mathrm{Na}$ institucionalização da enfermagem moderna estão presentes o saneamento do meio ambiente e a disciplina sobre os agentes, os mcsmos instrumentos da polícia médica, medicina social urbana e reorganização dos hospitais.

A identificação dos agentes causais m icrobianos traz um novo instrumental tecnologico para a enfermagem, em fins do século XIX e início do século $\mathrm{XX}$. O hospital, já disciplinado e hierarquizado, com seu ambiente sob controle, passa a ser o local para tratar as crianças com doenças transmissíveis, através do isolamento. Na realidade, a única medida terapêutica disponível nesta época era o isolamento em si mesmo, sob o olhar vigilante da cnfermeira. 
Ao final da década de $\mathbf{3 0}$ as enfermeiras pediatras identificam as limitações do referencial teórico insuficiente em fornecer elementos para lidar com a criança e ajudá-la, um ser em crescimento e desenvolvimento, temporariamente afastado de seu ambiente e da familia, durante a hospitalização.

Procura no estudo do crescimento e desenvolvimento infantil, referencial térico trazido em parte da psicologia, instrumentalizar-se para lidar com problemas de comportamento e ajudar nas relações entre a criança, a família e o conjunto de pessoas que compõem a equipe de saúde.

Através do estudo do instrumental teórico que a enfermeira utiliza, constata-se que o processo de trabalho em saúde é único, onde as atividades dos profissionais estão articuladas; as necessidades em saúde, coletivas, geram um processo de trabalho coletivo capaz de relativamente atendê-las. Os agentes socia is desse trabalho, que são de várias categorias profissionais, desenvolvem instrumentos, intelectuais e materiais, integrados no mesmo processo.

O conhecimento utilizado pela enfermagem, se não é absolutamente o mesmo utilizado pelo médico, está dentro da mesma formalização de raciocínio abstra to, próprio da racionalidade científica moderna onde a medicina se desenvolve.

O conhecimento de enfermagem passa a se diferenciar de saber médico à medida que a criança doente, para sua recuperação, precisa satisfazer necessidades, além das anátomo-patológicas; aquelas que a considerem como um ser em cresciemnto com sua individualidade, integrando-se ao meio ambiente.

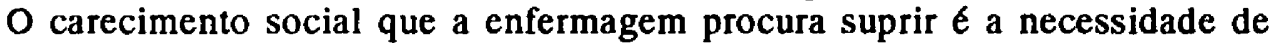
conforto, segurança, proteção, que estão mais acentuadas pela ocorrência da doença.

ROCHA, S.M.M.; ALMEIDA, M.C.P de The seginnins of the pediatrical nursing. Rev Esc. Enf. USP., v.27, n.1, p. 25-41, apr. 1993.

The object of study of this investigations in the knowledge in pediatrics nursing from the institutionalization of the modern nursing beginning from the XIX Century. The knowledge in this study is considered as an instrument from which man apprehends his working object. From an historical perspective nursing is seen as a social articulated pratice, as part of a collective process of works, whose purposes are: the control of the disease in the society, based on collective level and the recuperation of the individual working strenght.

Through the bibliography, we try to identify the characteristics of children's nursing assistance in England, during the XIX Century and the simultaneous movements of the medicinal practice: the social medicine, the clinic medical practice and puericulture. Followed the characteristics of the children's assistance in the United States in the beginning of the century and the theoretical reference in wich it is located.

UNITERMS: Historical of the Pediatrical Nursing. 


\section{REFERÊNCIAS BIBLIOGRÁFICAS}

1. ALMEIDA, M.C.P.; ROCHA, J.S.Y. Q saber de enfermageme sua dimensāo prática. São Paulo, Cortez, 1986.

2. BIER, O. Bacteriologia e imunologia: em suas aplicaçōes à medicina e à higiene. 9.ed., São Paulo, Ed. Melhoramentos, 1959.

3. CARVALHO, A.C. Qtientaçoe ensino de estudantes de enfermagem no campoclínico. São Paulo, 1. 1972. 150p. Tese (Doutorado) - Escola de Enfermagem, Universidade de São Paulo.

4. FOUCAULT, M. Microfísica de poder. Rio de Janeiro. Graal,1979.

5. FOUCAULT, M. Q nascimento da dínica. 2.ed. Rio de Janeiro, Forense Universitária, 1980.

6. MARX, K. O capital: crítica da economia política. São Paulo, Abril Cultural, 1984.

7. MENDES GONÇALVES, R.B. Tecnologia e organizacāo social das práticas de saúde: característi cas tecnológicas do processo de trabalho na rede estadual de Centros de Saúde de Sāo Paulo.

Sāo Paulo, 1986. 416p. Tese (Doutorado) - Facul dade de Medicina, Universidade de São Paulo.

8. O processo de trabalhe em saúde. São Paulo, Departamento de Medicina Preventiva da Faculdade de Medicina da USP, 1988 /Mi meografado.

9. NIGHIINGALE, F. Notas sobre enfermagem: o que é e o que não é. São Paulo, Cortez, 1989.

10. ROCHA, S.M.M. Puericul tura e enfermagem. Sāo Paulo, Cortez, 1987.

11. ROSEN, G. A evoluçăo da medi cina social. In: NUNES, E.D. Medicina social: aspectos hi stóricos e teóricos. Sāo Paulo, Global, 1983. p.25-82.

12. Da polícia médica à medicina social: ensaios sobre a história da assistência módica. Rio de Janeiro, Grall, 1979.

13. SAINT FRANCIS HOSPITAL SCHOOL OF NURSING. Course outline for student nurses in pediatrics. Hartford. Connecticut, s/d /Mimeografado/

14. SEYMER, R.L. Elorence Nightingale. Sāo Paulo, Melhoramentos, s/d.

15. SOUZA, A.M. de A. Desenvolvimento dos servicos de assessocia de enfermagem da Organizacäo Pan-Americana da Saúde: Impacto na educaçăo de enfermagem lati no-americana (1940-1980).

Ohio, 1982. 354p. Tese (Doutorado) - Graduate School of the Ohio State University.

16. WAECHTER, E.H.; BLAKE, F. Enfermagempediátric.9.ed. Rio de Janeiro, Interamerica, 1979. 


\section{ANEXO 1}

Quadro 1. Saint Francis School of Nursing Course Outlene for Student Nurses in Pediatrics Hartford, Connecticut $s / d$. p. 16-37.

\section{DISTRIBUIÇĀO DO CONTEÚdO E CARGA HORÁRIA} EM ENFER MA GEM PEDIÁTRICA.

\begin{tabular}{|c|c|c|c|}
\hline UNIDADE & CONTEÚDO PROGRAMÁTICO & \multicolumn{2}{|c|}{$\begin{array}{c}\text { CARGA HORÁRIA } \\
\text { NNHORAS }_{\%}{ }^{\circ} \text { HORAS }\end{array}$} \\
\hline I & Orientaçāo dos estudantes & 04 & 5,4 \\
\hline Il & Crescimento e desenvolvimento da criança & 10 & 13,5 \\
\hline III & Nutriçāo do lactente e da criança & 08 & 10,8 \\
\hline IV & $\begin{array}{l}\text { Cuidados de enfermagem referentes a: } \\
\text { trato respiratório } \\
\text { trato circulatório } \\
\text { trato uri nário } \\
\text { trato gastro-intestinal } \\
\text { sistema nervoso } \\
\text { condiçōes ortopédicas }\end{array}$ & 20 & 27,0 \\
\hline $\mathbf{V}$ & $\begin{array}{l}\text { Enfermagem em doenças de infância: } \\
\text { doenças respiratórias } \\
\text { difteria e tétano } \\
\text { sarampo } \\
\text { caxumba e escartatina } \\
\text { polimielite } \\
\text { coqueluche } \\
\text { febre tifóide } \\
\text { infecçāo por Richetsia } \\
\text { meningite } \\
\text { catapora } \\
\text { variola } \\
\text { raiva }\end{array}$ & 32 & 43,4 \\
\hline & CARGA HORÁRIA TOTAL & 74 & 100,0 \\
\hline
\end{tabular}

